\title{
Anticancer Potential of Palladium(II) Complexes With Schiff Bases Derived from 4- Aminoacetophenone Against Melanoma In Vitro
}

\author{
LUÍS EDUARDO SARTO ${ }^{1}$, ELBA PEREIRA DE GOIS ${ }^{2}$, GABRIELA GOMES DE ANDRADE $^{3}$, \\ MATEUS SILVEIRA DE ALMEIDA ${ }^{3}$, JENNIFER TAVARES JACON FREITAS ${ }^{4}$, \\ ANTÔNIO DE SOUZA REIS JÚNIOR ${ }^{2}$, LILIAN PEREIRA FRANCO ${ }^{4}$, CLAÚDIA TORRES $^{2}$, \\ EDUARDO TONON DE ALMEIDA ${ }^{2}$ and CIBELE MARLI CAÇÃO PAIVA GOUVÊA ${ }^{3}$ \\ ${ }^{1}$ Federal Institute of Education, Science and Technology of the South of Minas Gerais, Machado, Brazil; \\ ${ }^{2}$ Institute of Chemistry, Federal University of Alfenas, Alfenas, Brazil; \\ ${ }^{3}$ Institute of Natural Sciences, Federal University of Alfenas, Alfenas, Brazil; \\ ${ }^{4}$ Department of Food and Medicines, Faculty of Pharmaceuticals Sciences, \\ Federal University of Alfenas, Alfenas, Brazil
}

\begin{abstract}
Background/Aim: Melanoma represents a big challenge for clinical treatment. Besides being the most aggressive and the deadliest form of skin cancer, it is often refractory to commonly used anticancer drugs. Hence, developing new anti-cancer agents is crucial to improve refractory melanoma treatment. Studies using palladium(II) complexes have reported antitumor effects on cancer cells. In this study, we aimed to determine the cytotoxic effect of three novel synthesized Pd(II) complexes with Schiff bases derived from 4-aminoacetophenone on the MDA-MB-435 melanoma cell line. Materials and Methods: Cells were treated with ligand and Pd(II) complexes. Cell viability, morphology and death induction upon treatment were examined. Results: Novel synthesized Pd(II) complexes led to decreased viability of cells. They also induced morphological alterations and cell death, mainly in the C3 complex. Conclusion: The novel synthesized complexes have a significant cytotoxic effect on cell line MDA-MB-435, especially $C 3$ and can be considered as an antitumor agent for further studies.
\end{abstract}

Cancer poses a major threat to public health worldwide, and the incidence rates have increased in most countries (1). Globally, the most frequent kind of malignancy is skin

Correspondence to: Dr. Eduardo Tonon de Almeida, Institute of Chemistry, Federal University of Alfenas, Rua Gabriel Monteiro da Silva, 700, CEP 37130-000, Alfenas, Brazil. Tel: + 553537019712 , e-mail: tonon@unifal-mg.edu.br

Key Words: Antitumor effect, metal complexes, skin cancer, cell viability, cell death. cancer, which has been categorized into non-melanoma and melanoma skin cancers. Cutaneous melanoma is the deadliest form of skin cancer, its incidence varies greatly between countries, and has been increasing at a more rapid rate than other cancer types (2).

Treatment of cutaneous melanoma experienced a revolution over the past decade with the introduction of target therapy and immunotherapy. Although new therapies have achieved success in extending patient survival, most patients develop endocrine disfunctions (3) and become resistant to targeted therapy $(4,5)$ resulting in rapid progression with treatmentrefractory disease and once metastasized, the treatment options for melanoma become very limited $(6,7)$. In this scenario, chemotherapy remains important in the palliative treatment of persistent post-BRAF blockade, refractory, progressive, and relapsed melanomas (8).

After the discovery of cisplatin [cis-diamminedichloroplatinum(II)], a chemotherapeutic agent widely used against several tumor types, including melanoma, antitumor metallodrugs have emerged as potential alternatives for cancer treatment. This is the case of palladium(II) complex, a structurally analog to cisplatin, with reported cytotoxic activity against various cancer cell lines and lesser toxicity to normal cells (9-14). In this study, we synthesized novel Schiff base palladium(II) complexes derivated from 4-aminoacetophenone and evaluated their cytotoxic effects on melanoma cell line, MDA-MB-435.

\section{Materials and Methods}

Synthesis of imine ligands (L1-L3). A solution of p-anisaldehyde (8.28 $\mathrm{mmol})$, terephthaldehyde $(4.13 \mathrm{mmol})$ or trans-cinnamaldehyde $(8.26$ $\mathrm{mmol})$ in ethanol $(5 \mathrm{ml})$, was added dropwise to a solution of of 4 - 
aminoacetophenone $(8.28 \mathrm{mmol})$ in ethanol $(30 \mathrm{ml})$, to yield the $\mathrm{L} 1$, L2 and L3 ligands respectively (15). The reaction mixture was stirred at room temperature for $4 \mathrm{~h}$. After coolling for $24 \mathrm{~h}$, at $-10^{\circ} \mathrm{C}$, a pellet was formed which was filtered off, washed (with ethanol, water and ethyl ether) and vacuum-dried. L1 \{1-\{4-[(4-methoxyphenyl)methylideneamino]phenyl\}ethanone \}: yellow; yield 90\%; melting point: $126^{\circ} \mathrm{C}$; IR (KBr, cm $\left.{ }^{-1}\right): 2966,2841,1670,1589,1111,854 ;{ }^{1} \mathrm{H}$ NMR $\delta$ ppm (DMSO-d6, $300 \mathrm{MHz}$ ): 9.86 (s, 1H), 8.32-6.95 (m, 4H), 3.84 $(\mathrm{s}, 3 \mathrm{H}), 2.57$ (s, 3H); molar conductivity: $5.14 \mu \mathrm{S} / \mathrm{cm} ; \mathrm{C}_{16} \mathrm{H}_{15} \mathrm{NO}_{2}$ ( $253.29 \mathrm{~g} / \mathrm{mol})$; calculated (\%): C, 75.87; H, 5.97; N, 5.53; found (\%): C, 75.19; H, 5.68; N, 5.28. L2 \{1,1'-[1,4-phenylenebis(methylylidenenitrilo-4,1-phenylene)]diethanone\}: yellow; yield 91\%; melting point: $214^{\circ} \mathrm{C}$; IR $\left(\mathrm{KBr}, \mathrm{cm}^{-1}\right)$ : 2982, 2888, $1670,1578,1271,835 ; 1 \mathrm{H}$ NMR $\delta$ ppm (DMSO-d6, $300 \mathrm{MHz}$ ): 10.10 (s, 1H), 8.09 (s, 2H), 7.66 (s, 2H), $6.54(\mathrm{~s}, 2 \mathrm{H}), 2.36$ (s, 3H), molar conductivity: $3.86 \mu \mathrm{S} / \mathrm{cm}$; $\mathrm{C}_{24} \mathrm{H}_{20} \mathrm{~N}_{2} \mathrm{O}_{2}$ (368.42 g/mol); calculated (\%): C, 78.24; H, 5.47; N, 7.60; found (\%): C, 77.69; H, 5.29; N, 8.20. L3 \{1-\{4-[(3-phenylprop2-en-1-ylidene)amino]phenyl\}ethenone $\}$ : yellow; yield $86 \%$; melting point: $134^{\circ} \mathrm{C}, \mathrm{IR}\left(\mathrm{KBr}, \mathrm{cm}^{-1}\right)$ : 2991, 2855, 1670, 1578, 1262, 752; ${ }^{1} \mathrm{H}$ NMR $\delta$ ppm (DMSO-d6, $300 \mathrm{MHz}$ ): 9.65 (d, 1H, $J=7.8 \mathrm{~Hz}), 7.78-$ $7.59(\mathrm{~m}, 2 \mathrm{H}), 7.59-7.34(\mathrm{~m}, 3 \mathrm{H}), 7.30-7.08(\mathrm{~m}, 5 \mathrm{H}), 6.84(\mathrm{dd}, 1 \mathrm{H}$, $J=16.0,7.8 \mathrm{~Hz}), 2.32$ (d, 3H, $J=19.4 \mathrm{~Hz})$; molar conductivity: 3.54 $\mu \mathrm{S} / \mathrm{cm} ; \mathrm{C}_{17} \mathrm{H}_{15} \mathrm{NO}(249.30 \mathrm{~g} / \mathrm{mol})$; calculated (\%): C, 81.90; H, 6.06; $\mathrm{N}, 5.62$; found (\%): C, 81.54; H, 6.19; N, 5.29.

Synthesis of Pd(II) complexes (C1-C3). In order to synthesize the $\mathrm{Pd}(\mathrm{II})$ complexes C1, C2 and C3, a solution of each ligand L1, L2 or $\mathrm{L} 3$ respectively $(5.6 \mathrm{mmol})$ in methanol $(20.0 \mathrm{ml})$ was added dropwise to a solution containing palladium(II) chloride $(5.6 \mathrm{mmol})$ and lithium chloride $(11.28 \mathrm{mmol})$ dissolved in methanol $(50.0 \mathrm{ml})$. A mixture of triethylamine $(1.0 \mathrm{ml})$ and methanol $(15.0 \mathrm{ml})$ was then slowly added only for $\mathrm{C} 1$ synthesis. The resulting solutions were stirred at room temperature for $8 \mathrm{~h}$ and a pellet was formed which was filtered off, washed (with ethanol, water and ethyl ether) and vacuum-dried. C1: orange; yield $80 \%$; IR $\left(\mathrm{KBr}, \mathrm{cm}^{-1}\right): 2922$, 2841, 1680, 1581, 1112, 825; ${ }^{1} \mathrm{H}$ NMR $\delta$ ppm (DMSO-d6, 300 $\mathrm{MHz}): 10.15$ (s, 1H), 8.05-7.28 (m), 3.34 (s, 3H), 2.52 (s, 3H); molar conductivity: $24.52 \mu \mathrm{S} / \mathrm{cm} ; \mathrm{C}_{32} \mathrm{H}_{28} \mathrm{~N}_{2} \mathrm{O}_{4} \mathrm{Cl}_{2} \mathrm{Pd}_{2}(788.32$ $\mathrm{g} / \mathrm{mol}$ ); calculated (\%): C, 48.76; H, 3.58; N, 3.55; Pd, 27.00; found (\%): C, 48.15; H, 3.24; N, 3.13; Pd, 27.88. C2: orange; yield 48\%; IR (KBr): 2907, 2862, 1682, 1598, 1271, $835 \mathrm{~cm}^{-1} ;{ }^{1} \mathrm{H}$ NMR (DMSO-d6, $300 \mathrm{MHz}$ ): $\delta$ ppm: 10.11 (s, 1H), 8.10 (s, 4H), 7.65 (d, $2 \mathrm{H}, J=8.7 \mathrm{~Hz}), 6.55(\mathrm{~d}, 2 \mathrm{H}, J=8.7 \mathrm{~Hz}), 2.37(\mathrm{~s}, 3 \mathrm{H})$, molar conductivity: $3.60 \mu \mathrm{S} / \mathrm{cm} ; \mathrm{C}_{48} \mathrm{H}_{40} \mathrm{~N}_{4} \mathrm{O}_{4} \mathrm{Cl}_{4} \mathrm{Pd}_{2}(1091.51 \mathrm{~g} / \mathrm{mol})$; calculated (\%): C, 52.82; H, 3.69; N, 5.13; Pd, 19.5; found (\%): C, 53.05; H, 3.83; N, 5.39; Pd, 19.45. C3: yellow; yield 87\%; IR (KBr, $\left.\mathrm{cm}^{-1}\right): 2921,2857,1682,1573,1169,752 ;{ }^{1} \mathrm{H}$ NMR $\delta \mathrm{ppm}$ (DMSO-d6, $300 \mathrm{MHz})$ : 9.67 (d, 1H, $J=7.8 \mathrm{~Hz}), 7.76-7.64$ (m, 2H), 7.48-7.37 (m, 3H), 6.89-6.73 (m, 5H), $6.58(\mathrm{~d}, 1 \mathrm{H}, J=8.5 \mathrm{~Hz}), 2.37$ (s, $3 \mathrm{H}$ ); molar conductivity: $3.58 \mu \mathrm{S} / \mathrm{cm} ; \mathrm{C}_{34} \mathrm{H}_{30} \mathrm{~N}_{2} \mathrm{O}_{2} \mathrm{Cl}_{2} \mathrm{Pd}$ (675.94 $\mathrm{g} / \mathrm{mol}$ ); calculated (\%): C, 60.41; H, 4.47; N, 4.14; Pd, 15.74; found (\%): C, 61.10; H, 4.13; N, 4.44; Pd, 17.74 .

Cell line culture and treatment. The MDA-MB-435 cell line was purchased from the Rio de Janeiro Cell Bank (Brazil) and cultured in RPMI 1640, supplemented with $20 \%$ (v/v) inactivated fetal bovine serum, $100 \mathrm{U} / \mathrm{ml}$ penicillin and $100 \mu \mathrm{g} / \mathrm{ml}$ streptomycin. Cells were maintained in a humidified atmosphere with $5 \% \mathrm{CO}_{2}$, at $37^{\circ} \mathrm{C}$. Medium was replaced every two days and cells were subcultured every 3 days, after $0.25 \%$ Tripsina-EDTA solution
Table I. Cytotoxic activity of the compounds against MDA-MB-435 cancer cell line.

\begin{tabular}{lccc}
\hline \multirow{2}{*}{ Compound } & \multicolumn{2}{c}{$\mathrm{I}_{\max }(\%)$} & \multirow{2}{*}{$\mathrm{IC}_{50}(\mu \mathrm{M})$} \\
\cline { 2 - 3 } & $24 \mathrm{~h}$ & $48 \mathrm{~h}$ & \\
\hline Cisplatin & $31.46 \pm 1.75^{\mathrm{a}}$ & $65.30 \pm 3.95^{\mathrm{a}}$ & $6.00 \pm 0.34^{\mathrm{a}}$ \\
L1 & $28.87 \pm 1.20^{\mathrm{a}}$ & $66.48 \pm 1.07^{\mathrm{a}}$ & $6.7 \pm 0.21^{\mathrm{a}}$ \\
C1 & $40.91 \pm 1.82^{\mathrm{b}}$ & $73.31 \pm 1.24^{\mathrm{a}}$ & $5.33 \pm 0.24^{\mathrm{a}}$ \\
L2 & $11.99 \pm 1.95^{\mathrm{c}}$ & $67.62 \pm 1.35^{\mathrm{a}}$ & $6.45 \pm 0.27^{\mathrm{a}}$ \\
C2 & $33.09 \pm 2.76^{\mathrm{a}} \mathrm{b}$ & $85.72 \pm 2.17^{\mathrm{b}}$ & $2.86 \pm 0.04^{\mathrm{b}}$ \\
L3 & $15.88 \pm 1.69^{\mathrm{c}}$ & $72.99 \pm 2.15^{\mathrm{a}}$ & $5.40 \pm 0.43^{\mathrm{a}}$ \\
C3 & $44.54 \pm 1.29^{\mathrm{b}}$ & $80.13 \pm 1.24^{\mathrm{b}}$ & $3.97 \pm 0.02^{\mathrm{b}}$ \\
\hline
\end{tabular}

$I_{\max }$ : Maximal inhibition of viability achieved after 24 and $48 \mathrm{~h}$ of treatment with $10 \mu \mathrm{M}$ of each compound. $\mathrm{IC}_{50}$ : concentration required to reduce the cell viability by $50 \%$ of the maximum effect of the compound after $48 \mathrm{~h}$ of treatment (relative to negative control). The results were obtained by the SRB assay and are shown as mean \pm SEM of three independent experiments. Different letters in the same column indicate significant differences $(p<0.05)$ by the Tukey's test.

treatment. The Trypan blue-dye exclusion method was used to assess cell viability before each experiment and exponentially growing cells were plated at seeding density of $2 \times 10^{4}$ cells $/ \mathrm{ml}$ and left overnight to allow for attachment. The cells were then exposed for 24 or $48 \mathrm{~h}$ to L1-L3 and C1-C3 different concentrations (0.1$10.0 \mu \mathrm{M})$. Compounds were freshly dissolved in DMSO, sterilized by filtration and diluted in the culture medium. Treated-cells with vehicule were the negative control, and with cisplatin, the positive.

Sulforhodamine B (SRB) viability assay. The cytotoxicity of the compounds was evaluated using SRB cell viability, which estimated cell protein content (16). Control and treated-cells, seeded onto 96well plates, were fixed with $10 \%$ trichloroacetic acid $(w / v)$ for 30 min at $4^{\circ} \mathrm{C}$, then washed three times with distilled water and dried for $24 \mathrm{~h}$. The fixed cellular material was stained with $0.4 \%$ SRB dissolved in $1 \%$ acetic acid (v/v) for $30 \mathrm{~min}$. Unbound dye was removed by rinsing 4 times with $1 \%$ acetic acid $(\mathrm{v} / \mathrm{v})$. The proteinbound dye was dissolved by adding $100 \mu \mathrm{l}$ of $10 \mu \mathrm{M}$ Tris, $\mathrm{pH} 10.5$ for the determination of optical density (at $510 \mathrm{~nm}$ ) in a BiochromAsys UVM 340 microplate reader. Vibility of treated cells was calculated relative to the negative control and the obtained values were used to determine the $\mathrm{IC}_{50}$ (concentration necessary to reach $50 \%$ of the maximum inhibitory effect of the compound).

Cell morphological and morphometric analyses. Control and treated cells cultured on coverslips were fixed with $70 \%$ acetone for $15 \mathrm{~min}$, washed with PBS, and stained with hematoxylin-eosin. Slides were observed by light microscopy, after being mounted in Entellan. Cell digital images were acquired using an Olympus BX52 microscope and Motic Images Plus 2.0 software. Fifteen random fields were analyzed per treatment, to describe cell morphology. Cell length was determined by measuring 150 cells per treatment (15).

Cell death assay. Cell death was estimated using the fast green-dye exclusion method (17), with modifications (18). Control and treatedcells were stained with $2 \%$ Fast green, followed by hematoxylin- 


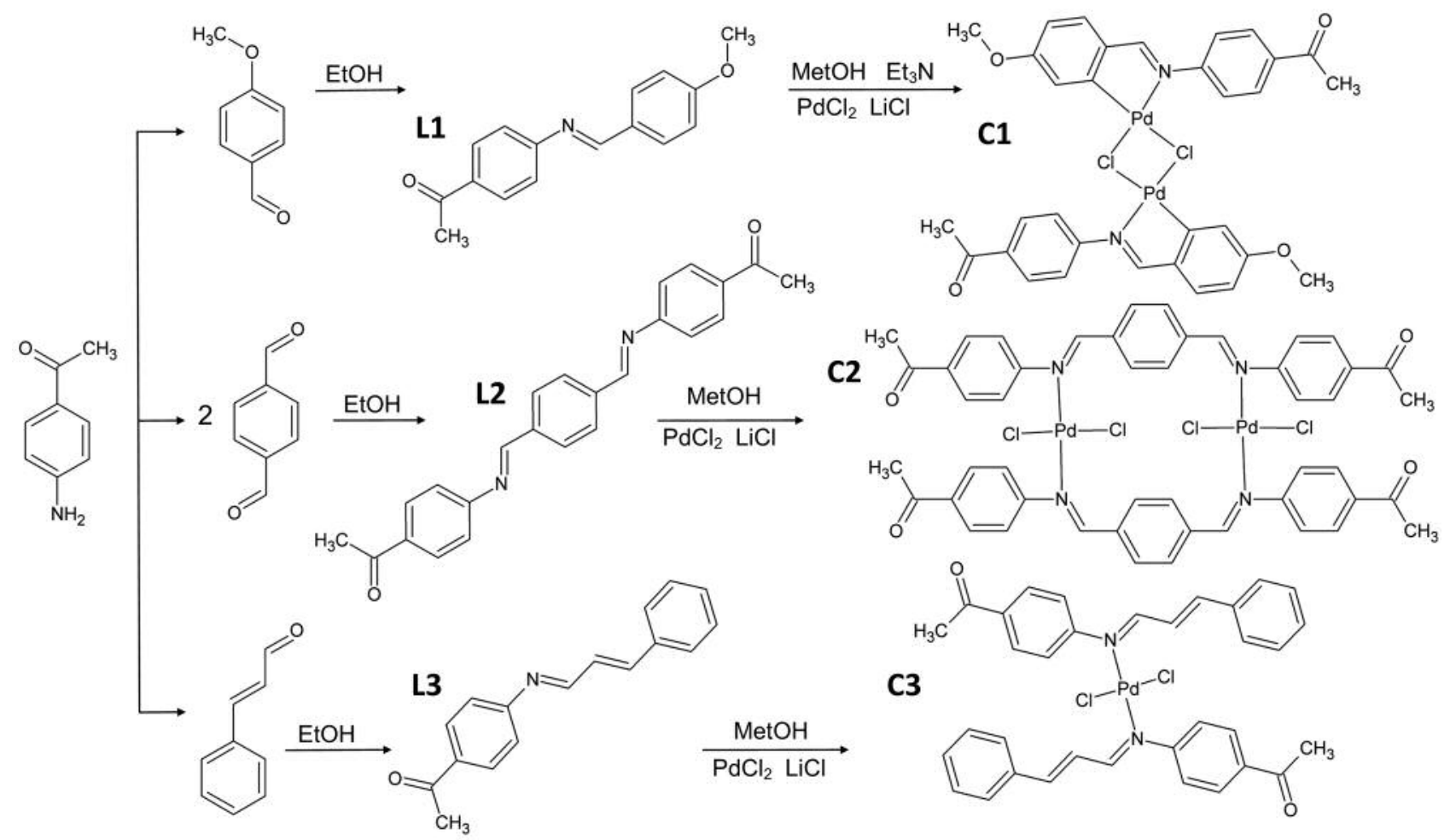

Figure 1. Synthesis of 4-aminoacetophenone ligands (L1-L3) and of the Pd(II) complexes (C1-C3).

eosin, and slides were mounted in Entellan. Based on this method, viable cells exclude Fast green, so they were reddish-pink stained, while dead cells were stained green, as they are unable to exclude Fast green. We analyzed 600 cells/treatment using an Olympus BX52 microscope and Motic Images Plus 2.0 software, to obtain the percentage of dead cells.

Statistical analysis. Obtained data were compared by one-way analysis of variance (ANOVA) followed by the Tukey test, when $p$ value was less than 0.05 . Data are shown as the mean \pm SEM of three independent experiments.

\section{Results}

Chemistry. The metal palladium(II) has a planar square geometry and the coordination occurs by iminic nitrogen. In C1 complex, the metal also binds to a carbon atom, forming a cyclopalladated compound (Figure 1). All spectral, elemental and thermal analysis agreed with the proposed structures.

Cell viability. Cell viability decreased upon compound treatment, and the effect was concentration and timedependent (Table I). Additionally, C2 and C3 were able to reduce cell viability by more than $80 \%$ upon treatment for $48 \mathrm{~h}$, an effect that is not frequently observed in apoptosis- resistant cell lines. Compounds exhibited micromolar $\mathrm{IC}_{50}$ values. Of note, $\mathrm{C} 2$ and $\mathrm{C} 3$ exhibited the highest potencies compared to the other compounds, with $\mathrm{IC}_{50}$ of 2.86 and $3.97 \mu \mathrm{M}$, respectively.

Morphology and morphometry. Ligands and $\operatorname{Pd}(\mathrm{II})$ complexes treatment induced alterations in MDA-MB-435 cell morphology. Negative control cells are irregular-shaped cells, with nuclear and cytoplasmic pleomorphism, cytoplasm less stained than the nucleus and the nucleolus plainly visible. After exposure to the compounds, cells exhibited chromatin condensation, rounding-up and shrinkage that indicate cytoskeleton disruption. The effect of compounds increased with the incubation time increasing (Figure 2). The $\mathrm{Pd}(\mathrm{II})$ complexes produced more conspicuous morphological changes than the respective ligands, specially C3. Cell shrinkage was further confirmed by the determination of cell length, which was significantly $(p<0.05)$ decreased in comparison to control cells. The most active compound was C3 (Figure 3).

Cell death. Cisplatin and compounds treatment induced significant $(p<0.01)$ cell death, with $\mathrm{C} 3$ being the most efficient $\mathrm{Pd}(\mathrm{II})$ complex (Figure 4). 

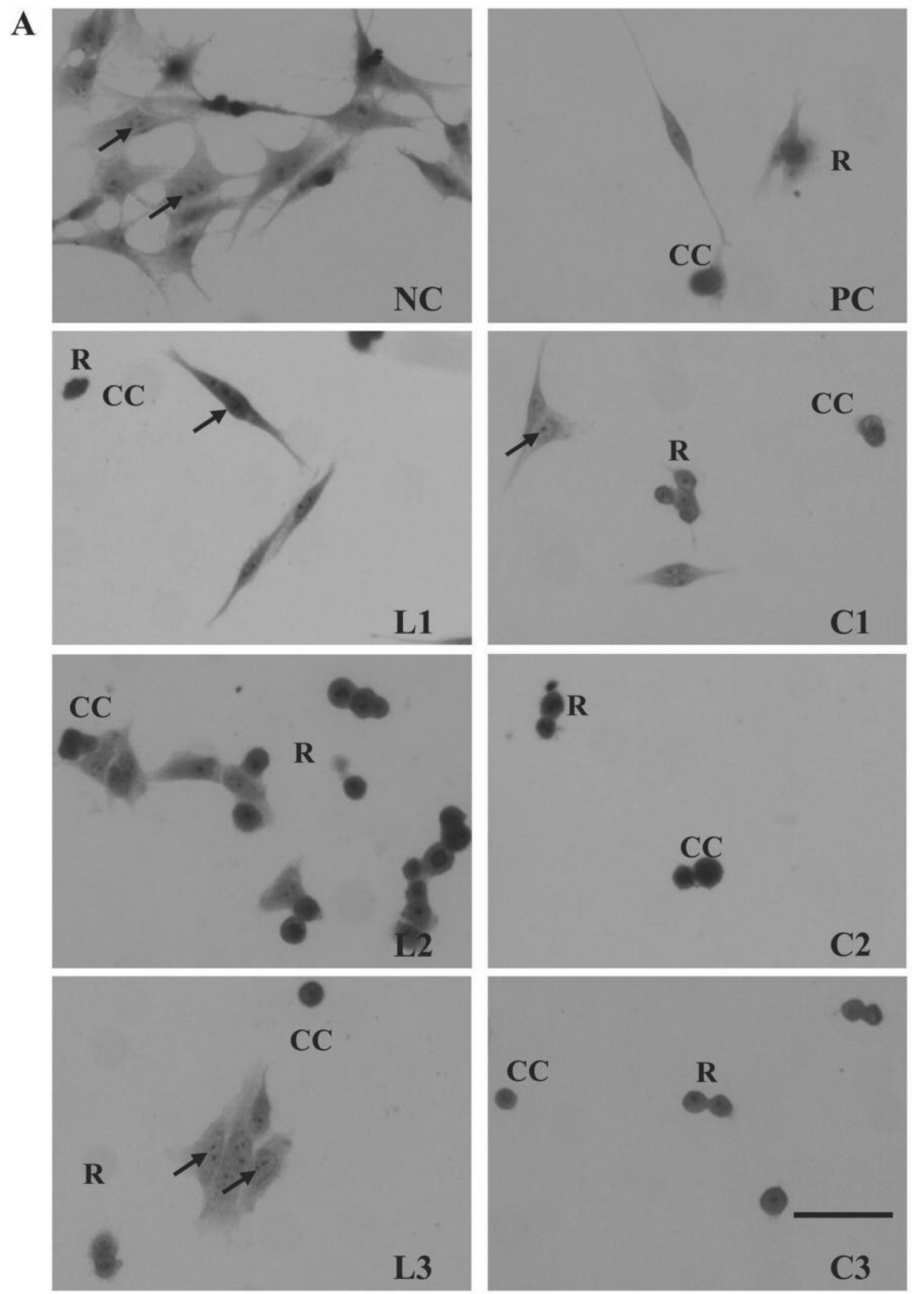

Figure 2. Continued 

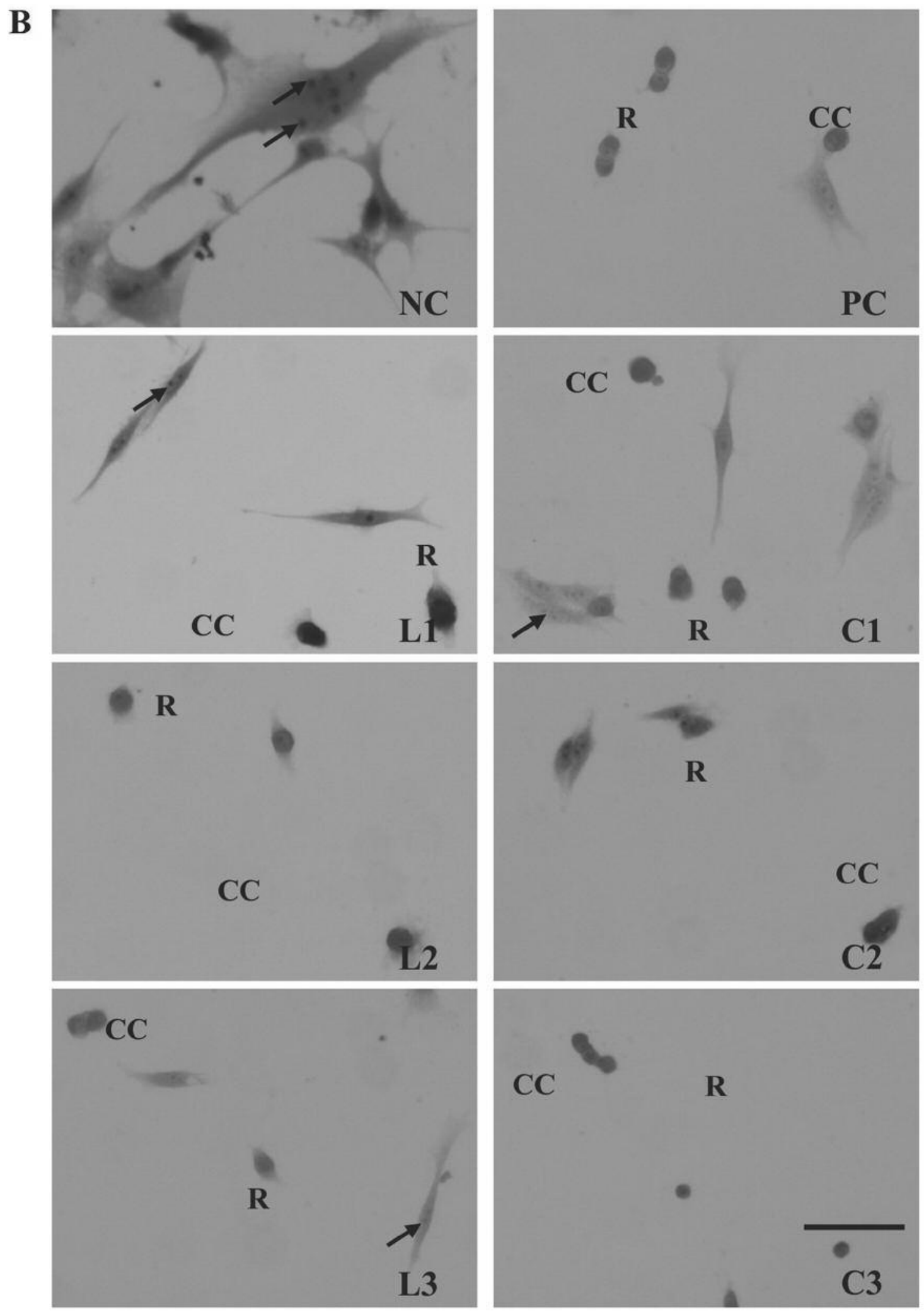

Figure 2. Morphology of control and treated MDA-MB-435 cells stained with hematoxylin and eosin, after $24 h(A)$ and $48 h(B)$ incubation. NC, Negative control; PC, cisplatin (positive-control); L1-L3, ligands; C1-C3, Pd(II) complexes. The compounds were used at $5 \mu M$. All the experiments were carried out in triplicates on different occasions, under identical conditions. Bar $=5 \mu \mathrm{m}$. Arrow: nucleolus; $R$ : rounding; CC: chromatin condensation. 


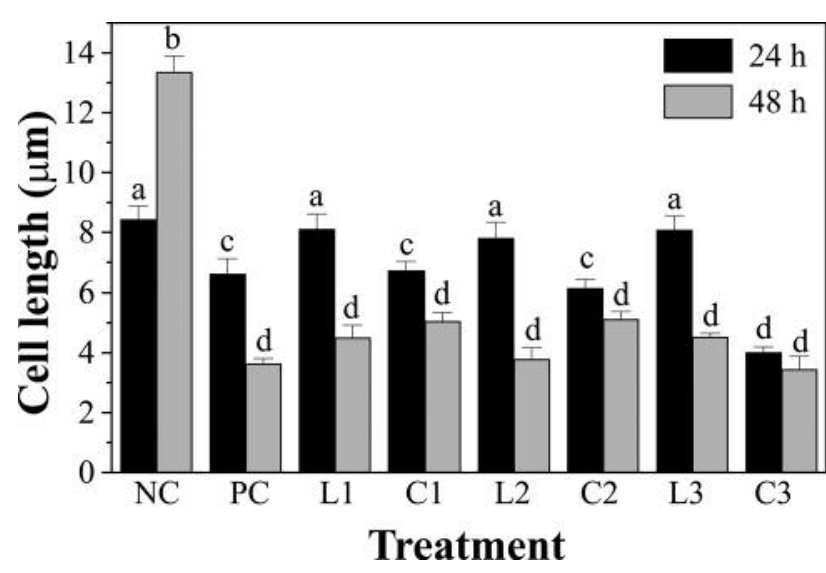

Figure 3. Control and treated MDA-MB-435 cell length ( $\mu \mathrm{m})$ after 24 and 48 h incubation. NC, Negative-control; PC, cisplatin (positivecontrol); L1-L3, ligands; C1-C3, Pd(II) complexes. The compounds were used at $5 \mu M$. Results are expressed as mean \pm SEM of three independent experiments. Different letters indicate significant differences $(p<0.05)$ by the Tukey's test .

\section{Discussion}

In the present study, we report the in vitro antitumor potential of three newly synthesized Schiff base palladium(II) complexes derivated from 4aminoacetophenone. The presented coordination fashions were based on similar structures reported in literature with determined crystallographic structures (19-21). It has been demonstrated that $\mathrm{Pd}(\mathrm{II})$ coordination to Schiff bases improves its biological activity (22) and that was also observed in the present work. Even though ligands exhibited cytotoxic activity towards MDA-MB-435 cells, the coordination with $\mathrm{Pd}(\mathrm{II})$ improved the observed activity. In a previous study we have also demonstrated the cytotoxic effect of a palladium(II) imine ligand complex on MDA-MB-435 (15), however, with a lesser activity than $\mathrm{C} 3$. It is also interesting to point out that $\mathrm{C} 2$ and $\mathrm{C} 3$ had $\mathrm{IC}_{50}$ values lower than cisplatin and dacarbazine, a classic chemotherapy drug used in the treatment of melanoma (23).

Decreasing protein content could be correlated to cell number, thus being an indicator of cell growth or to the protein turnover, affecting cell viability. Therefore, it is possible to sustain the positive cytotoxic role of compounds in the inhibition of MDA-MB-435 cell growth and spread, thus affecting cell viability.

The cytotoxic potential of Pd(II) complexes against the MDA-MB-435 cancer cell line was also endorsed by the demonstration of their effects on cell morphology, such as

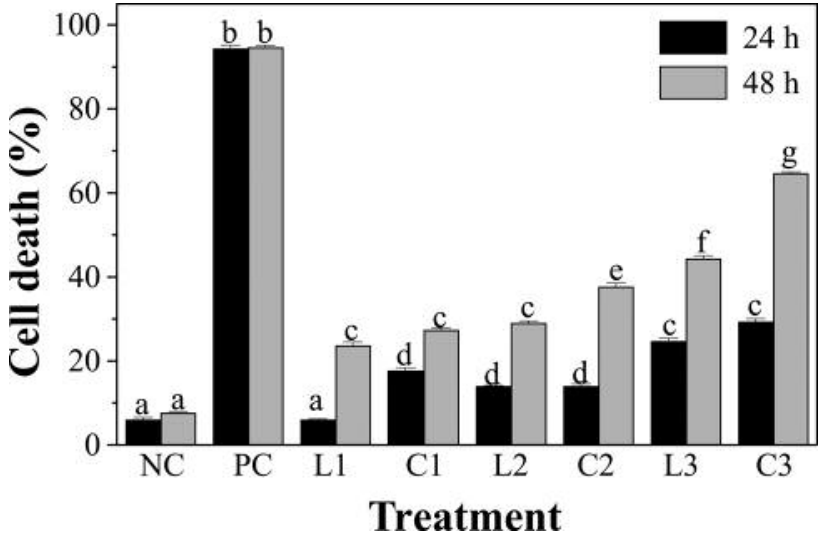

Figure 4. Control and treated MDA-MB-435 cell death (\%) after $24 \mathrm{~h}$ and 48 h incubation. NC, Negative control cells; PC, cisplatin (positivecontrol); L1-L3, ligands; C1-C3, Pd(II) complexes. The compounds were used at $5 \mu M$. Results are expressed as mean \pm SEM of three independent experiments. Different letters indicate significant differences $(p<0.01)$ by the Tukey's test.

rounding-up (probably by disrupting cytoskeleton), shrinkage of the cell and margination of chromatin in the nucleus which are signs of cell death induction (24).

Most melanoma tumors are resistant to cell death $(6,25)$ and the present work showed that $\mathrm{Pd}(\mathrm{II})$ complexes, mainly C3, induced cell death, which could be important for counteracting cancer development and spread, thus being an important feature of a candidate for new antineoplastic drug development. Our findings are in agreement with reported work showing PD (II) complexes' cytotoxicity to melanoma cells both in vitro and in vivo, using a xenograft model (12-14).

Overall, the results of the present work support a positive cytotoxic effect of Pd(II) complexes towards MDA-MB-435, an invasive melanoma cancer cell line, especially $\mathrm{C} 3$ which may be a promising candidate for antineoplastic drug development. Further in vitro experiments and animal studies have to be performed to support these findings.

\section{Conflicts of Interest}

The Authors declare that there are no conflicts of interest regarding this study.

\section{Authors' Contributions}

All Authors were responsible for: substantial contributions to conception, design, acquisition of data, analysis and interpretation of data, drafting the manuscript, revising the manuscript critically for important intellectual content, and final approval of the version to be published. 


\section{Acknowledgements}

The Authors gratefully acknowledge FAPEMIG for financial support (Grants: CEX - APQ-01984-14 and Rede Mineira de Química- REDE-113/10) and the fellowships from: CAPES (EPG), FAPEMIG (GGA), CNPq (ETA) and PET-MEC-SESu (CMCPG).

\section{References}

1 Bray F, Ferlay J, Soerjomataram I, Siegel RL, Torre LA and Jemal A: Global cancer statistics 2018: GLOBOCAN estimates of incidence and mortality worldwide for 36 cancers in 185 countries. CA Cancer J Clin 68(6): 394-424, 2018. PMID: 30207593. DOI: $10.3322 /$ caac. 21492

2 Leonardi GC, Falzone L, Salemi R, Zanghì A, Spandidos DA, Mccubrey JA, Candido S and Libra M: Cutaneous melanoma: From pathogenesis to therapy (Review). Int J Oncol 52(4): 10711080, 2018. PMID: 29532857. DOI: 10.3892/ijo.2018.4287

3 Ariyasu H, Inaba H, Ota T, Yamaoka H, Furukawa Y, Iwakura H, Doi N, Yamamoto Y and Akamizu T: Thyrotoxicosis and adrenocortical hormone deficiency during immune-checkpoint inhibitor treatment for malignant melanoma. In Vivo 32(2): 345351, 2018. PMID: 29475919. DOI: 10.21873/invivo.11244

4 Hargadon KM, Gyorffy B, Strong EW, Tarnai BD, Thompson JC, Bushhouse DZ, Johnson CE and Williams CJ: The FOXC2 transcription factor promotes melanoma outgrowth and regulates expression of genes associated with drug resistance and interferon responsiveness. Cancer Genomics Proteomics 16(6): 491-503, 2019. PMID: 31659103. DOI: $10.21873 / \mathrm{cgp} .20152$

5 Mazzio EA and Soliman KFA: Whole-transcriptomic profile of SK-MEL-3 melanoma cells treated with the histone deacetylase inhibitor: Trichostatin A. Cancer Genomics Proteomics 15(5): 349-364, 2018. PMID: 30194076. DOI: $10.21873 /$ cgp.20094

6 Bai X, Fisher DE and Flaherty KT: Cell-state dynamics and therapeutic resistance in melanoma from the perspective of MITF and IFN $\gamma$ pathways. Nat Rev Clin Oncol 16(9): 549-562, 2019. PMID: 30967646. DOI: 10.1038/s41571-019-0204-6

7 Domingues B, Lopes JM, Soares P and Pópulo H: Melanoma treatment in review. Immunotargets Ther 7: 35-49, 2018. PMID: 29922629. DOI: 10.2147/ITT.S134842

8 Wilson MA and Schuchter LM: Chemotherapy for melanoma. Cancer Treat Res 167: 209-29, 2016. PMID: 26601864. DOI: 10.1007/978-3-319-22539-5_8

9 Kapdi AR and Fairlamb IJ: Anti-cancer palladium complexes: a focus on PdX2L2, palladacycles and related complexes. Chem Soc Rev 43(13): 4751-4777, 2014. PMID: 24723061. DOI: $10.1039 / \mathrm{c} 4 \mathrm{cs} 00063 \mathrm{c}$

10 Fanelli M, Formica M, Fusi V, Giorgi L, Micheloni M and Paoli P: New trends in platinum and palladium complexes as antineoplastic. Coord Chem Rev 310: 41-79, 2016. DOI:10.1016/j.ccr.2015.11.004

11 Jahromi EZ, Divsalar A, Saboury AA, Khaleghizadeh S, Mansouri Torshizi $\mathrm{H}$ and Kostova I: Palladium complexes: new candidates for anti cancer drugs. J Iran Chem Soc 13: 967-989, 2016. DOI: $10.1007 / \mathrm{s} 13738-015-0804-8$

12 Serrano FA, Matsuo AL, Monteforte PT, Bechara A, Smaili SS, Santana DP, Rodrigues T, Pereira FV, Silva LS, Machado J Jr, Santos EL, Pesquero JB, Martins RM, Travassos LR, Caires AC and Rodrigues EG: A cyclopalladated complex interacts with mitochondrial membrane thiol-groups and induces the apoptotic intrinsic pathway in murine and cisplatin-resistant human tumor cells. BMC Cancer 11: 296, 2011. PMID: 21756336. DOI: 10.1186/1471-2407-11-296

13 Gigli R, Pereira GJ, Antunes F, Bechara A, Garcia DM, Spindola DG, Jasiulionis MG, Caires AC, Smaili SS and Bincoletto C: The biphosphinic paladacycle complex induces melanoma cell death through lysosomal-mitochondrial axis modulation and impaired autophagy. Eur J Med Chem 107: 245-254, 2016. PMID: 26599531. DOI: 10.1016/j.ejmech.2015.11.008

14 Elsey J, Bubley JA, Zhu L, Rao S, Sasaki M, Pollack BP, Yang $\mathrm{L}$ and Arbiser JL: Palladium based nanoparticles for the treatment of advanced melanoma. Sci Rep 9(1): 3255, 2019. PMID: 30824801. DOI: 10.1038/s41598-019-40258-6

15 Campanella NC, Demartini MS, Torres C, Almeida ET and Gouvêa CMCP: The cytotoxic and growth inhibitory effects of palladium(II) complexes on MDA-MB-435 cells. Genet Mol Biol 35(1): 159-163,2012. PMID: 22481890. DOI: 10.1590/ S1415-47572012005000016

16 Vichai V and Kirtikara K: Sulforhodamine B colorimetric assay for cytotoxicity screening. Nat Protoc 1(3): 1112-1116, 2006. PMID: 17406391. DOI: 10.1038/nprot.2006.179

17 Weisenthal LM, Marsden JA, Dill PL and Macaluso CK: A novel dye exclusion method for testing in vitro chemosensitivity of human tumors. Cancer Res 43(2): 749-757, 1983. PMID: 6184155.

18 Carvalho AJS, Ishikawa T and Gouvêa CMCP: Aqueous extract of Plinia edulis leaves: Antioxidant activity and cytotoxicity to human breast cancer MCF-7 cell line. S Afr J Bot 81: 1-7, 2012. DOI: $10.1016 /$ j.sajb.2012.03.010

19 Hejda M, Dostál L, Jambor R, Ruzicka A, Jirásko R and Holecek J: Synthesis, Structure and transmetalation activity of various C, Y-chelated organogold(I) compounds. Eur J Inorg Chem 2012(15): 2578-02587, 2012. DOI: 10.1016/j.jorganchem. 2011.07.044

20 Pal S, Hwang WS, Lin IJ and Lee CS: Benzene benzimidazole containing Pd(II) metallacycle: Synthesis, X-ray crystallographic characterization and its use as an efficient Suzuki coupling catalyst. J Mol Catal A-Chem 269(1-2): 197-203, 2007. DOI: 10.1016/j.molcata.2007.01.028

$21 \mathrm{Hu} \mathrm{ZX}$, Ma N, Zhang JH, Hu WP and Wang HX: Palladium meditated CPhenyl-H bond activation of 2-furylimines versus tert-2-furylbenzylamines. Polyhedron 83: 30-35, 2014. DOI: 10.1016/j.poly.2014.03.041

22 Malik MA, Dar OA, Gull P, Wani MY and Hashmi AA: Heterocyclic Schiff base transition metal complexes in antimicrobial and anticancer chemotherapy. Medchemcomm 9(3): 409-436, 2017. PMID: 30108933. DOI: 10.1039/c7md00526a

23 Al-Qatati A and Aliwaini S: Combined pitavastatin and dacarbazine treatment activates apoptosis and autophagy resulting in synergistic cytotoxicity in melanoma cells. Oncol Lett 14(6): 7993-7999, 2017. PMID: 29344241. DOI: 10.3892/ol.2017.7189

24 D'Arcy MS: Cell death: a review of the major forms of apoptosis, necrosis and autophagy. Cell Biol Int 43(6): 582-592, 2019. PMID: 30958602. DOI: 10.1002/cbin.11137

25 Kalal BS, Upadhya D and Pai VR: Chemotherapy resistance mechanisms in advanced skin cancer. Oncol Rev 11(1): 326, 2017. PMID: 28382191. DOI: 10.4081/oncol.2017.326

Received October 23, 2019

Revised November 3, 2019

Accepted November 6, 2019 